\title{
PHYTOCHEMICAL SCREENING, ACUTE TOXICITY , ANALGESIC AND ANTI- INFLAMMATORY EFFECTS OF APRICOT SEEDS ETHANOLIC EXTRACTS
}

\author{
Ramadan A. ${ }^{1}$, Gehan Kamel ${ }^{1}$, Nagwa E. Awad ${ }^{2}$, Aya A. Shokry ${ }^{1 *}$. \\ ${ }^{1}$ Department of Pharmacology, Faculty of Veterinary Medicine, Cairo University, Cairo, Egypt. \\ ${ }^{2}$ Department of Pharmacognosy, Pharmaceutical and Drug Industrial Research Division, National \\ Research Center, Cairo, Egypt. \\ *Corresponding author's E-mail: ayaabdelsalam333@gmail.com
}

\begin{abstract}
The aim of present study was to investigate the phytochemical screening, acute toxicity and some pharmacological activities of ethanolic extract $70 \%$ and $99.9 \%$ of apricot seeds. The phytochemical screening was done for determination of total phenolic compounds by Folin-Ciocalteu method, total flavonoids by aluminum chloride colorimetric method and total carotenoids by colorimetric method. The acute toxicity was done for determination of $\mathrm{LD}_{50}$ in mice by oral administration of upgraded doses of the extracts. The antiinflammatory activity was done in vivo by formalin-induced paw edema in rats. The analgesic activity was carried out in mice by writhing test and hot plate method. Phytochemical screening revealed that the amount of total phenolic compounds was 179.4 and $191.2 \mu \mathrm{g}$ gallic acid equivalent / g dry extract and the amount of total flavonoids was 226.18 and $509.34 \mu \mathrm{g}$ rutin equivalent / g dry extract and the amount of total carotenoids was 0.145 and $0.156 \mathrm{mg} / \mathrm{g}$ dry extract for $70 \%$ and $99.9 \%$ ethanolic extract, respectively. The acute toxicity revealed that both extracts had no toxic symptoms in rats and no mortalities appear by upgraded doses of $1 \mathrm{~g}$ to $10 \mathrm{~g} / \mathrm{kg}$ b.wt. The $70 \%$ and $99.9 \%$ ethanolic extracts exhibited significant analgesic and anti-inflammatory activites in a dose of 100 $\mathrm{mg} / \mathrm{kg}$ b.wt. of both extracts. These results suggest that apricot seed extracts contain significant level of safe non-toxic phytochemical substances that have significant analgesic and anti-inflammatory activities.
\end{abstract}

Original Article:

Received 8 june. 2018

Accepted 22 June. 2018

Published 12 July 2018

Key words: Analgesic, Anti-inflammatory, Apricot seed, LD50, Phytochemical.

J. Appl. Vet. Sci., 3(1): 26-33.

\section{INTRODUCTION}

Apricot (Prunus armeniaca L.) is classified under the Prunus species of Rosaceae family of the Rosales group. Apricot has an important role in human diet, and can be used as fresh, dried or processed fruit (Gezer et al. 2011). Apricots are processed in large amounts and huge consumption of apricot fruit produced by large amount of seeds (Gornas et al. 2015). The apricot has been used in folk medicine for the treatment of different diseases. The bark of apricot tree used in the form of decoction with soothing effect can be applied on irritated skin. Other uses for apricots in folk medicine include treatment of hemorrhages, infertility, eye inflammation, and spasm (Chevallier, 1996). The different parts of the plant are used as food additives (Asma et al. 2007).

Armeniacae semen is the seed of the apricot, the inner part of the apricot ( Hwang et al. 2008).
Apricot seeds are usually roasted and mixed with coriander seeds and salt used as Dokka to be eaten as part of Egyptian folk diet (Abdel-rahman 2011). It is known that apricot seeds are exported to European countries to be used in medicine, cosmetic and oil production (Gezer et al. 2002). Apricot seeds are added to bakery products (as whole or ground) in retail bakeries and also consumed as appetizers (Durmaz and Alpaslan 2007). Armeniacae semen is known to have many therapeutic effects such as relieving fever, respiratory symptoms such as wheeze, asthma, emphysema and bronchitis, stopping cough, quenching thirst. In traditional oriental medicine, Armeniacae semen has been used for the treatment of asthma, bronchitis, emphysema, constipation, nausea, leprosy, and leukoderma (Hwang et al. 2003 and Bensky et al. 2004). 


\section{Ramadan A, et al.}

Apricot kernel paste can heal vaginal infections. The kernel oil has been used in cosmetics and as a pharmaceutical agent (laxative and expectorant). (Chevallier, 1996). It has been used for treating skin diseases such as furuncle, acne vulgaris and dandruff, as well as constipation (Ju et al., 2004). Armeniacae semen is divided into the outer husk and an inner part that contains glycoside, amygdaline, starch, and fatty acids (Chang et al. 2005). Some fruit seeds such as cherry, apricot, citrus and apple can be used as good source of oils. These seed oils are used for several purposes such as blending with highly saturated edible oils which are expensive to provide new oils with modified nutritional values as ingredients in paint and varnish formulations, surface coatings and oleo-chemicals, and as oils for cosmetic purposes ( Helmy 1990).

There is no general utilization of apricot seeds, usually the amount that is collected goes into the adulteration of both almond kernels and their oil (Aggarwal et al. 1974). The aim of the present study was to explore and confirm the phytochemical screening of apricot seed extracts followed by determination of toxicological effect of these extracts on rats and then determination of some pharmacological activities of these extracts in vivo.

\section{MATERIALS AND METHODS} Seeds:

Apricot seeds were collected from Edfina factory from Alexandria during the season of apricot production.

\section{Seeds preparation:}

The seeds were washed, dried and then the kernels were splitted from the shell. After that, the internal kernels were kept in bags tightly closed in the freezer for preparation of the extract.

\section{Extract preparation:}

\section{Ethanolic extract 99.9\%:}

The kernels were soaked in $99.9 \%$ ethanol solution at room temperature. The kernels were grinded in a mortar using pestle and then exposed to boiling for $100 \mathrm{~min}$, at $55{ }^{\circ} \mathrm{C}$. Extract was then filtered through a layer gauze. The solvent was removed using rotatory evaporator apparatus attached with vacuum pump and temperature $40-50{ }^{\circ} \mathrm{C}$. The yield was chilled in a refrigerator until use.

\section{Ethanolic extract $70 \%$ :}

Another type of extract was obtained by using $70 \%$ ethanol solution and $6 \%$ citric acid. The seeds were put in blender with water and citric acid till complete grinding and then the seeds put in flask containing $70 \%$ ethanol solution for boiling at $55{ }^{\circ} \mathrm{C}$ for $100 \mathrm{~min}$. Extract was then filtered. The solvent was removed using rotatory evaporator apparatus attached with vacuum pump and temperature was $40-50^{\circ} \mathrm{C}$. The yield was chilled in a refrigerator until use.

\section{Animals:}

Mature mice of both sexes and weighing (20$25 \mathrm{~g}$ ) were used for studying the acute toxicity, LD50 and analgesic activity. Mature albino rats of both sexes and weighing (200-250 g) were used to reveal the antiinflammatory activity. Standard rat pellets and tap water were supplied ad libitum.

\section{Chemicals:}

All chemicals were purchased from SigmaUSA, Aldrich. Solvents were purchased from El Nasr Pharmaceutical chemicals Co., Egypt.

\section{Phytochemical screening:}

\section{Determination of total phenolic content:}

The total phenolic content of the extracts was determined spectrophotometrically by Folin-Ciocalteu method as described by Baba \& Malik (2015). Gallic acid was used as the reference standard and the results were expressed as $\mu \mathrm{g}$ of gallic acid equivalent per gram extract.

\section{Determination of total carotenoid content:}

The total carotenoid content of the extracts was determined spectrophotometrically by the method described by Schertz (1923). The extracts were reconstituted in 1 to $10 \mathrm{ml}$ of acetone and sonicated for 2 min. visible spectra (340 to $700 \mathrm{~nm}, 1 \mathrm{~nm}$ interval )were collected using a $1 \mathrm{ml}$ quartz cuvette in a $\mathrm{UV} /$ visible spectrophotometer.

\section{Determination of total flavonoid content:}

The total flavonoid content of crude extracts was determined by aluminum chloride colorimetric method as described by Baba \& Malik (2015). Rutin was used as a reference standard and the results were expressed as $\mu \mathrm{g}$ Rutin equivalent / gram of the extract.

\section{Determination of acute toxicity:}

A pilot experiment was performed to determine $\mathrm{LD}_{50}$ of $70 \%$ and $99.9 \%$ ethanolic extracts of apricot seeds. The $\mathrm{LD}_{50}$ was determined using method described by Kerber (1941). For this purpose 5 groups of five mice each weighing 20-25 g were administrated orally in upgrading doses ranging from 1000 to 10000 $\mathrm{mg} / \mathrm{kg}$ b.wt. Another group was left as control and given vehicle only. The toxic symptoms and mortality rate in each group was recorded 72 hours post administration. The $\mathrm{LD}_{50}$ of the tested extract was calculated according to the formula using method described by Kerber (1941). 


\section{Determination of anti-inflammatory activity:}

According to the method described by Domenjoz et al. (1995). Thirty rats of both sexes weighing 200-250 g were used. Rats were divided into five equal groups of five rats each. Rats of the first group were left as negative control (no inflammation, no treatment). Rats of the second group were left as positive control with induced inflammation only. The animals of the third group were orally administered indomethacin as standard drug in a dose of $10 \mathrm{mg} / \mathrm{kg}$ b.wt. ( Akindele \& Adeyemi 2007). Rats of the fourth and fifth groups were orally administered $70 \%$ and $99.9 \%$ ethanolic extracts at a dose of $100 \mathrm{mg} / \mathrm{kg}$ b.wt. Thirty minutes after drug or tested compound administration, $0.1 \mathrm{ml}$ of $2.5 \%$ formalin solution in normal saline was injected subcutaneously in the right hand paw of all animals for induction of edema. The thickness of each rat paw was measured in $\mathrm{mm}$ by Vernier caliber after 1, 2, 3, 4 and 5 hours post administration.

\section{Determination of analgesic activity:}

\section{A) Acetic acid induced writhing test:}

This method was used to evaluate the possible peripheral effects of ethanloic extracts of apricot seeds. This experiment was carried as described by Okun et al. (1963). Thirty mice of both sexes weighing 20-25 g were selected and divided into 4 groups. Mice of the first group were kept as control non-treated, those of the second group were orally administered diclofenac sodium in a dose of $25 \mathrm{mg} / \mathrm{kg}$ b.wt. as a standard group (Ahmed et al. 2004). Mice of the third and fourth groups were orally administered $70 \%$ and $99.9 \%$ ethanolic extract in a dose of $100 \mathrm{mg} / \mathrm{kg}$ b.wt. After 30 minutes, each mouse was intraperitoneally injected with $0.25 \mathrm{ml}$ of $0.7 \%$ glacial acetic acid in distilled water and the mice were then placed in transparent boxes for observation of writhing (arching of back, turning of trunk (twist), extension of hind limbs, contraction of abdominal musculature, torsion to one side so that the belly of the mouse touch the floor. Number of writhes of each animal in all groups was recorded within 30 min. and the analgesic potency of the tested extracts was determined as protection \% against writhing according to the following formula:

$\%$ of protection $=\underline{\text { control mean }- \text { treated mean }} \times 100$

control mean

\section{B) Eddy's Hot plate test:}

The hot plate test was employed for assessment of possible centrally mediated analgesic effects of ethanolic extracts of apricot seeds. The experiment was carried out as described by Janssen and Jageneau (1957) and modified by Jacob and Bosovski (1961) using hot plate apparatus, thermostatically controlled at
$55 \pm 0.5{ }^{\circ} \mathrm{C}$. Thirty mice were divided into 4 groups, 5 animals each. Reaction time (licking of paws or jumping off the hot plate) was measured prior to extract (min 0 ) and after the drug treatment. Mice of the first group were kept as control non-treated group. Mice of the second group were orally administered ibuprofen at a dose of $50 \mathrm{mg} / \mathrm{kg} \mathrm{b}$.wt. as a standard drug. Mice of the third and fourth groups were orally administered $70 \%$ and $99.9 \%$ ethanolic extract in a dose of $100 \mathrm{mg} / \mathrm{kg}$ b.wt., respectively. The reaction time was measured at $30 \mathrm{~min}$. and repeated at 60,90 and $120 \mathrm{~min}$. post administration.

\section{Statistical analysis:}

Data were presented as means \pm standard errors. Data were analyzed using commercial software statistical package for social science (SPSS version $(16)$. The significance level at $P$ value $\leq 0.05$ is considered significant.

\section{Extract preparation:}

\section{RESULTS}

\section{Ethanolic extract 99.9\%:}

Each 250 gram seeds yielded $70 \pm 2$ gm of

dried extract after complete evaporation of ethanol.

\section{Ethanolic extract 70\%:}

Each 250 gram seeds yielded $170 \pm 2$ gm of dried extract after complete evaporation of ethanol.

\section{Determination of total phenols, total flavonoids, and total carotenoids in both $70 \%$ and $99.9 \%$ ethanolic extracts:}

The amount of total phenolic compounds, total flavonoids and total carotenoids are listed in Table (1).

Table .1: The amount of total phenols, total flavonoids, and total carotenoids in both $70 \%$ and $99.9 \%$ ethanolic extracts.

\begin{tabular}{|c|c|c|}
\hline & $\begin{array}{c}70 \% \\
\text { Ethanolic } \\
\text { Extract }\end{array}$ & $\begin{array}{c}99.9 \% \\
\text { Ethanolic } \\
\text { Extract }\end{array}$ \\
\hline $\begin{array}{c}\text { Total phenols } \\
\text { ( } \mu \text { g gallic acid } \\
\text { equivalent / g dry } \\
\text { extract ) }\end{array}$ & 179.4 & 191.2 \\
\hline $\begin{array}{c}\text { Total flavonoids } \\
\text { ( } \mu \mathrm{g} \text { rutin equivalent / } \\
\mathrm{g} \text { dry extract })\end{array}$ & 226.18 & 509.34 \\
\hline $\begin{array}{l}\text { Total carotenoids } \\
(\mathrm{mg} / \mathrm{g})\end{array}$ & 0.145 & 0.156 \\
\hline $\begin{array}{c}\beta \text { - carotene } \\
(\mathrm{mg} / \mathrm{g})\end{array}$ & 0.01 & 0.01 \\
\hline
\end{tabular}




\section{Determination of acute toxicity:}

After oral administration of both $70 \%$, 99.9\% ethanolic extract of apricot seeds in rats in a dose of $1,3,5,10 \mathrm{~g} / \mathrm{kg}$ b.wt. No deaths were observed during the $72 \mathrm{hr}$ period at the tested doses. At these doses, the animals showed no toxic symptoms. The median lethal dose (LD50) was determined to be higher than highest tested dose in both samples. These results indicate the safety of the tested samples.

\section{Determination of anti-inflammatory activity:}

The anti-inflammatory effect of the $70 \%$ and $99.9 \%$ ethanolic extracts of apricot seeds was studied using formalin induced paw edema in rats and data were compared with that of control in Table (2). Oral administration of $70 \%$ and $99.9 \%$ ethanolic extracts of apricot seeds in a dose of 100 $\mathrm{mg} / \mathrm{kg}$ b.wt. induced a significant decrease in inflamed rat paw thickness when compared with control non treated group for 4 hours.

\section{Determination of analgesic activity:}

\section{A) Writhing test:}

The peripheral anti-nociceptive activity of the $70 \%$ and $99.9 \%$ ethanolic extracts of apricot seeds was studied using acetic acid induced writhing technique in mice and the results were recorded in Table (3).

\section{B) Hot plate test:}

Results of central anti-nociceptive activity of the $70 \%$ and $99.9 \%$ ethanolic extracts of apricot seeds are recorded in Table (4).

\section{DISCUSSION}

This study investigated the phytochemical and toxicological and some pharmacological activity of Apricot seed extracts. The phytochemical screening included determination of total phenols, total flavonoids, total carotenoids and $\beta$-carotene in both 70 $\%$ and $99.9 \%$ of armeniacae semen ethanolic extracts. The total phenolic content of the ethanolic extracts, calculated from the calibration curve $(R 2=0.9978)$, was $179.4,191.2 \mu \mathrm{g}$ gallic acid equivalents/g dry extract in both70 \% and $99.9 \%$ ethanolic extracts respectively, the total flavonoid contents $(R 2=0.9959)$ were 226.18 and $509.34 \mu \mathrm{g}$ rutin equivalents/g dry extract in both $70 \%$ and $99.9 \%$ ethanolic extracts, respectively. The total carotenoids were 0.145 and $0.156 \mathrm{mg} / \mathrm{g}$ dry extract in both70 \% and $99.9 \%$ ethanolic extracts. respectively, and $\beta$ - carotene content was $0.01 \mathrm{mg} / \mathrm{g}$ dry extract in both70 \% and $99.9 \%$ ethanolic extracts respectively as shown in (Table 1). Phenolic compounds have redox properties, so they can act as antioxidants and act as free radical terminators (Soobrattee et al. $2005 \&$ Shahadi et al. 1992). They have free radical scavenging ability which is facilitated by their hydroxyl groups, the total phenolic concentration could be used as an indicator for rapid screening of total antioxidant capacity of the extract. Flavonoids, including flavones, flavanols and condensed tannins, are plant secondary metabolites, the antioxidant activity of which depends on the presence of free $\mathrm{OH}$ groups, especially $3-\mathrm{OH}$. Plant flavonoids act as effective antioxidant in vitro and in vivo (Geetha et al. 2003 \& Shimoi et al. 1996).

It has been recognized that flavonoids show antioxidant activity and their effects on human nutrition and health should be considered. The mechanisms of action of flavonoids as antioxidants are through scavenging or chelating process (Kessler et al. 2003 \& Cook and Samman 1996). Carotenoids are plant pigments that function as antioxidants, hormone precursors, colorants and essential components of the photosynthetic apparatus. The presence of carotenoids in food crops are essential components for human diets ( Howitt \& Pogson 1992). $\beta$-carotene is a precursor of vitamin A (Yeum \& Russell 2002), and lutein and zeaxanthin have been implicated in preventing macular degeneration (Landrum \& Bone 2004). The concentrations of total flavonoids. Phenolic compounds , carotenoids indicate that $70 \%$ and $99.9 \%$ ethanolic apricot seed extract act as effective antioxidants with high free radical scavenging capacity.

The in-vivo anti-inflammatory activity of the extracts was studied using formalin induced paw edema in rats and data were compared with that of control. Oral administration of $70 \%$ and $99.9 \%$ ethanolic extracts in a dose of $100 \mathrm{mg} / \mathrm{kg}$ induced a significant decrease in inflamed rat paw thickness. These results matched with previously obtained by Badr \& Tawfik (2010) who reported that apricot kernel extract possesd marked an anti-inflammatory activity in histamine-induced paw edema in rats. Induction of edema in rat's paw by formalin is a biphasic response, in which the first phase is mediated by histamine, serotonin and kinins and then the second phase is mediated by prostaglandins (cyclooxygenase product of arachidonic acid metabolism) and production of reactive oxygen species (ROS) (Chen, 1993 \& Panthong et al., 2004). The effect of apricot seed extract as anti-inflammatory may be attributed by inhibition of pro-inflammatory cytokines and COX-2 synthesis and reduction in prostaglandin synthesis and this was reported by Chang et al., (2005) who showed that Armeniacae semen exerts anti-inflammatory and analgesic effects by suppression of cyclooxygenase- 2 and inducible nitric oxide synthase expressions. Armeniacae semen 
extract inhibited LPS-stimulated enhancement of COX2 enzyme activity and PGE2 production in the mouse BV2 microglial cells. Elevation of COX-2 activity is closely associated with the occurrence of cancers, arthritis, and several types of neurodegenerative disorders. PGE2, a major metabolite of the COX-2 pathway, has emerged as an important lipid mediator of inflammatory and immunoregulatory processes. PGE2 has been implicated in the pathogenesis of acute and chronic inflammatory disease states (Hinz et al., 2000). Specific COX-2 inhibitors are also known to attenuate the symptoms of inflammation (Shao et al., 2000). From our results we can suggest that apricot seed extract has powerful anti-inflammatory effect.

The analgesic activity of both extracts was determined using both writhing test and hot plate test. In writhing test, the standard group showed $77.37 \%$ protection against writhing induced by glacial acetic acid. Oral administration of $70 \%$ and $99.9 \%$ ethanolic extracts in a dose of $100 \mathrm{mg} / \mathrm{kg}$ induced a significant analgesic activity with $68.99 \%$ and $67.88 \%$ protection percentage. In hot plate test, the data showed that both $70 \%$ and $99.9 \%$ ethanolic extracts induced significant analgesic activity. These results matched with previously obtained by Badr \& Tawfik (2010) who reported that apricot kernel extract had a marked analgesic activity when administered orally. The mechanism of the analgesic action may be due to inhibition of release of endogenous substances that excite pain nerve endings, which is mediated via a peripheral mechanism (Jing-Rong et al. 2008).

\section{CONCLUSION}

Ethanolic apricot seed extracts are safe and non-toxic with some pharmacological activities as analgesic and anti-inflammatory activities. These effects may be attributed to presence of biochemical ingredients such as phenolic compounds, flavonoids and carotenoids. These date confirm the therapeutic medicinal importance of apricot seeds.

Table 2. The anti-inflammatory effect of $70 \%$ and $99.9 \%$ ethanolic extracts of apricot seeds in formalin induced paw edema in rats. $(n=5)$.

\begin{tabular}{|c|c|c|c|c|c|c|c|}
\hline \multirow[t]{2}{*}{ Treatment } & \multirow{2}{*}{$\begin{array}{c}\text { Dose } \\
\text { (mg/kg } \\
\text { b.wt.) }\end{array}$} & \multicolumn{6}{|c|}{ Mean of right paw thickness in $\mathrm{mm}$} \\
\hline & & Pre -reatment & 1 hours & 2 hours & 3 hours & 4 hours & 5 hours \\
\hline Control & 0 & $\begin{array}{c}0.71 \pm \\
0.02\end{array}$ & $\begin{array}{c}0.72 \pm \\
0.02\end{array}$ & $\begin{array}{c}0.79 \pm \\
0.03\end{array}$ & $\begin{array}{c}0.85 \pm \\
0.02\end{array}$ & $\begin{array}{c}0.86 \pm \\
0.02\end{array}$ & $\begin{array}{c}0.86 \pm \\
0.02\end{array}$ \\
\hline $\begin{array}{l}\text { Indomethacin } \\
\text { (standard) }\end{array}$ & 10 & $\begin{array}{c}0.71 \pm \\
0.02\end{array}$ & $\begin{array}{l}0.58 \pm \\
0.01^{\mathrm{a}}\end{array}$ & $\begin{array}{l}0.51 \pm \\
0.02^{\mathrm{a}}\end{array}$ & $\begin{array}{c}0.5 \pm \\
0.02^{\mathrm{ab}}\end{array}$ & $\begin{array}{l}0.48 \pm \\
0.02^{\mathrm{ab}}\end{array}$ & $\begin{array}{c}0.5 \pm \\
0.02^{\mathrm{ab}}\end{array}$ \\
\hline $\begin{array}{l}99.9 \% \text { ethanolic } \\
\text { extract }\end{array}$ & 100 & $\begin{array}{c}0.71 \pm \\
0.02\end{array}$ & $\begin{array}{l}0.60 \pm \\
0.02^{\mathrm{a}}\end{array}$ & $\begin{array}{l}0.58 \pm \\
0.01^{\mathrm{a}}\end{array}$ & $\begin{array}{l}0.56 \pm \\
0.02^{\mathrm{b}}\end{array}$ & $\begin{array}{l}0.54 \pm \\
0.01^{\mathrm{b}}\end{array}$ & $\begin{array}{l}0.56 \pm \\
0.01^{\mathrm{b}}\end{array}$ \\
\hline $\begin{array}{l}70 \% \text { ethanolic } \\
\text { extract }\end{array}$ & 100 & $\begin{array}{c}0.71 \pm \\
0.02\end{array}$ & $\begin{array}{l}0.56 \pm \\
0.01^{\text {a }}\end{array}$ & $\begin{array}{l}0.52 \pm \\
0.02^{\mathrm{a}}\end{array}$ & $\begin{array}{l}0.52 \pm \\
0.01^{\mathrm{b}}\end{array}$ & $\begin{array}{l}0.53 \pm \\
0.01^{\mathrm{b}}\end{array}$ & $\begin{array}{l}0.51 \pm \\
0.01^{\mathrm{b}}\end{array}$ \\
\hline
\end{tabular}

The values represent the mean \pm S.E. of five animals for each group. Values in the column with different superscript letters (a,b ) are significantly different at $\mathrm{P}<0.05$ when compared with control. Data were analyzed by using One-way ANOVA followed by Duncan test. 


\section{Ramadan A, et al.}

Table 3. The peripheral anti-nociceptive activity of the $70 \%$ and $99.9 \%$ ethanolic extracts of apricot seeds using acetic acid induced writhing technique in mice. $(n=5)$.

\begin{tabular}{|l|c|c|c|}
\hline Treatment & $\begin{array}{c}\text { Dose (mg/kg } \\
\text { b.wt.) }\end{array}$ & $\begin{array}{c}\text { No. of Writhes in } \\
30 \mathrm{~min} .\end{array}$ & \begin{tabular}{c} 
\% of protection \\
\hline Control
\end{tabular} \\
\hline Diclofenac sodium (standard) & 25 & $16.2 \pm 0.6^{\mathrm{b}}$ & $77.37 \%$ \\
\hline $99.9 \%$ ethanolic extract & 100 & $23 \pm 0.7^{\mathrm{a}}$ & $67.88 \%$ \\
\hline $70 \%$ ethanolic extract & 100 & $22.2 \pm 0.9^{\mathrm{a}}$ & $68.99 \%$ \\
\hline
\end{tabular}

The values represent the mean \pm S.E. of five animals for each group. Values in the column with different superscript letters (a,b ) are significantly different at $\mathrm{P}<0.05$ when compared with control. Data were analyzed by using One-way ANOVA followed by Duncan test.

Table 4. The central anti-nociceptive activity of the $70 \%$ and $99.9 \%$ ethanolic extracts of apricot seeds using hot plate test.

\begin{tabular}{|l|c|c|c|c|c|}
\hline Treatment & $\begin{array}{c}\text { Dose }(\mathrm{mg} / \mathrm{kg} \\
\text { b.wt.) }\end{array}$ & 0.5 hours & 1 hours & 1.5 hours & \multicolumn{2}{l|}{2 hours } \\
\hline Control & 0 & $7.8 \pm 0.8$ & $8.8 \pm 0.4$ & $7.4 \pm 0.5$ & $7.8 \pm 0.8$ \\
\hline Ibuprofen & 50 & $14 \pm 0.7^{\mathrm{b}}$ & $14 \pm 0.6^{\mathrm{b}}$ & $16.8 \pm 0.6^{\mathrm{b}}$ & $16.8 \pm 0.5^{\mathrm{b}}$ \\
\hline (standard) & 100 & $12.6 \pm 0.5^{\mathrm{a}}$ & $13.2 \pm 0.6^{\mathrm{a}}$ & $13 \pm 0.7^{\mathrm{a}}$ & $14.8 \pm 0.4^{\mathrm{a}}$ \\
\hline 99.9\% ethanolic & 100 & $12.6 \pm 0.5^{\mathrm{a}}$ & $13.2 \pm 0.6^{\mathrm{a}}$ & $13.6 \pm 0.7^{\mathrm{a}}$ & $15 \pm 0.7^{\mathrm{a}}$ \\
\hline $70 \%$ ethanolic & & & & & \\
\hline extract & & & & & \\
\hline
\end{tabular}

The values represent the mean \pm S.E. of five animals for each group. Values in each column with different superscript letters (a,b ) are significantly different at $\mathrm{P}<0.05$ when compared with control. Data were analyzed by using One-way ANOVA followed by Duncan test. 


\section{REFERENCES}

ABDEL-RAHMAN, M.K. 2011. Can apricot kernels fatty acids delay the atrophied hepatocytes from progression to fibrosis in dimethyl nitrosamine (DMN) -induced liver injury in rats ? Lipids in Health and Disease. 10(114): 1-10.

AGGARWAL，K.K., RASSOD，J.K., BEDDI, K.L., NARASHIMA, L. 1974. Commercial utilization of wild apricot kernels. Journal of Oil Technologist's Association of India. 6: 67-69.

AHMED, F., SELIM, M.S.T., DA, A.K., CHOUDHURI, M.S.K. 2004. Anti-inflammatory and antinociceptive activities of Lippia nodiflora Linn. Pharmazie. 59: 329-330.

AKINDELE, A.J., ADEYEMI, O.O. 2007. Antiinflammatory activity of the aqueous leaf extract of Byrsocarpus coccineus. Fitoterapia. 8: 25-28.

ASMA, B.M., KAN, T., BIRHANLI, O. 2007. Characterization of promising apricot (Prunus armeniaca L.) Genetic resources in Malatya, Turkey. Genetic Resources and Crop Evolution. 54 (1):205212.

BABA, S.A., MALIK, S.A. 2015. Determination of total phenolic and flavonoid content, antimicrobial and antioxidant activity of a root extract of Arisaema jacquemontii Blume. Journal of Tilbian University for Science. 9(4): 449-454.

BADR, J., TAWFIK, M.K. 2014. Analytical and Pharmacological Investigation of Amygdalin in Prunus armeniaca L. Kernels. Journal of Pharmacy Research. 3(9): 2134-2137.

BENSKY, D., CLAVEY, S., STOGER, E. 2004. Chinese Herbal Medicine: Materia Medica, 3rd edition. Eastland Press: Seattle. 437-440.

CHANG, H.K., YANG, H.Y., LEE, T.H., SHIN, M.C., LEE, M.H., SHIN, M.S., KIM, C.J., KIM, O.J., HONG, S.P., CHO, S. 2005. Armeniacae semen extract suppresses lipopolysaccharide-induced expressions of cycloosygenase- 2 and inducible nitric oxide synthase in mouse BV2 microglial cells. Biological and Pharmaceutical Bulletin. 28(3): 449454.

CHEN, Q. 1993. Methodology in pharmacological study on Chinese materia medica. Beijing: 7 people's Medical publishing house. 360 .

CHEVALLIER A. 1996. The encyclopedia of medicinal plants. New York: DK Publishing.

COOK, N.C., SAMMAN, S. 1996. Flavonoids chemistry, metabolism, cardioprotective effects, and dietary sources. Nutritional Biochemistry. 7: 66-76.

DOMENJOZ, R., THEOBALD, W., STENGER, E.G., MORSDORF, K. 1995. The Effect of AntiInflammatory Agents on formalin edema and on the vitamin $\mathrm{C}$ and cholesterol content of the adrenal glands in hypophysectomized Rats. Archives internationals de pharmacodynamie et de Thérapie. 103(2-3): 341-352.

DURMAZ， G., ALPASLAN, M. 2007. Antioxidant properties of roasted apricot (Prunus armeniaca L.)Kernel. Food Chemistry. 100: 1177-1181.
GEETHA, S., SAI-RAM, M., MONGIA, S.S., SINGH, V., ILAVAZHA-GAN, G., SAWHNEY, R.C. 2003. Evaluation of antioxidant activity of leaf extract of seabuckthorn (Hippophae rhamnoides L.) on chromium (VI) induced oxidative stress in albino rats. Journal of Ethnopharmacology. 87(23): 247251.

GEZER, I., HACISEFEROGULLARI, H., DEMIR, F. 2002. Some physical properties of Hacihaliloglu apricot pit and its kernel. Journal of Food Engineering. 56: 49-57.

GEZER, I., HACISEFEROGULLARI, H., OZCAN, M.M., ARSLAN, D., ASMA, B.M., UNVER, A. 2011. Physico-chemical properties of apricot (prunus armeniaca 1.) kernels. South Western Journal of Horticulture, Biology and Environment. 2(1): 1-13.

GORNAS, P., MISINA, I., GRAVITE, I., SOLIVEN, A., KAUFMANE, E., SEGLIN,A, D. 2015. Tocochromanols composition in kernels recovered from different apricot varieties: RP-HPLC/FLD and RP-UPLC-ESI/MSn study. Natural Product Research. 29(13): 1222-1227.

HELMY, H.E. 1990. Studies on the pigments of some citrus, prune and cucurbit seed oils when processed with or without cottonseed oil. Journal of the American Oil Chemists' Society. 67(6): 376-380.

HINZ, B., BRUNE, K., PAHL, A. 2000. Prostaglandin E2 upregulates cyclooxygenase-2 expression in lipopolysaccharide-stimulated RAW 264.7 macrophages. Biochemical and Biophysical research Communications, 272 (3), 744-748.

HOWITT, C.A., POGSON, B.J. 2006. Carotenoid accumulation and function in seeds and non-green tissues. Plant, Cell and Environment. 29: 435-445.

HWANG, D.R., KANG, Y.S., KIM, S.S., KIM, D.H., SHIN, M.K., SONG, H.J. 2003. Studies on the allergic asthma effect of semen armeniaceae amarum. The Korea Journal of Herbology. 18(2): 201-208.

HWANG, H.J, KIM, P., KIM, C.J., LEE, H.J., SHIM, I., YIN, C.S., YANG, Y., HAHM, D.H. 2008. Antinociceptive effect of amygdalin isolated from Prunus armeniaca on formalin-induced pain in rats. Biological \& Pharmaceutical Bulletin. 31(8): 1559. 1564.

HWANG, H.J., LEE, H., KIM, C., SHIM, I., HAHM, D. 2008. Inhibitory Effect of Amygdalin on Lipopolysaccharide-Inducible TNF- $\alpha$ and IL-1 $\beta$ mRNA Expression and Carrageenan-Induced Rat Arthritis. Journal of Microbiology and Biotechnology. 18(10): 1641-1647.

JACOB, J., BOSOVSKI, M. 1961. Screening methods in Pharmacology Academic press INC., New York and London. 104-106.

JANSSEN, P.A., JAGENEAU, A.H. 1957. A new series of potent analgesics: dextro 2:2-diphenyl-3-methyl-4morpholino-butyrylpyrrolidine and related amides. I. Chemical structure and pharmacological activity. Journal of Pharmacy and Pharmacology. 9(6): 381400

JING-RONG, W., HUA，Z., ZHI-HONG，J., YUEN FAN, W., LIANG, L. 2008. In Vivo Antiinflammatory and Analgesic Activities of a Purified 
Saponin Fraction Derived from the Root of Ilex pubescens, Biological and Pharmaceutical Bulletin. 31: 643-650.

JU, Y.S., KIM, K.Y., CHANG, S.H. 2004. Miyong Donguibogam. [Korean] Seoungbosa: Seoul.

KERBER, G. 1941. Pharmakolgishe Methoden Zur Auffindung Von Arzneimitten Und Gifter Und Analyse Ihrer Wirkungweise Vor. Dr. Med Leopold Ther. Wissen schaftliche Verlage Gerlarge Geese Gesellschaft M. B. H.

KESSLER, M., UBEAUD, G., JUNG, L. 2003. Antiand pro-oxidant activity of rutin and quercetin derivatives. Journal of Pharmacy and Pharmacology. 55(1): 131-142.

LANDRUM, J.T., BONE, R.A. 2004. Dietary lutein and zeaxanthin: reducing the risk for macular degeneration. Agro Food Industry Hi-Tech. 15(6): 22-25.

OKUN, R.N., ANUAGASI, C.L., LASAGANAL, L. 1963. Screening methods in the effect of aggregation, electric shock and adrenergic blocking drugs on inhibition of the writhing syndrome. Journal of pharmacology and experimental therapeutics. 139: 107-114.

PANTHONG, A., KANJANAPOTHI, D., TAESOTIKUL, T., PHANKUMMOON, A., PANTHOG, K., REUTRAKUL, V. 2004. Antiinflammatory activity of methanolic extracts from ventilago harmandianapierre. Journal of Ethnopharmacology. 91(2-3): 237-242.

SCHERTZ, F.M. 1923. The quantitative determination of carotene by means of the spectrophotometer and colorimeter. Journal of Agriculture Research. 26: 383-400.

SHAHADI, F., JANITHA, P.K., WANASUNDARA, P.D. 1992. Phenolic antioxidants. Critical Reviews in Food Science and Nutrition. 32(1): 67-103.

SHAO, J., SHENG, H., INOUE, H., MORROW, J.D., DUBOIS, R.N. 2000. Regulation of constitutive cyclooxygenase-2 expression in colon carcinoma cells. Journal of Biological Chemistry. 275(43), 33951-33956.

SHIMOI, K., MASUDA, S., SHEN, B., FURUGORI, M., KINZE, N. 1996. Radio-protective effects of antioxidative plant flavonoids in mice. Mutation Research/ Fundamental and Molecular mechanisms of mutagenesis. 350: 153-161.

SOOBRATTEE, M., NEERGHEEN, V.S., LUXIMONRAMMA, A., AROMA, O.I., BAHORUN, O.T. 2005. Phenolics as potential antioxidant therapeutic agents: mechanism and actions. Mutation Research/ Fundamental and Molecular mechanisms of mutagenesis. 579(1): 200-213.

YEUM, K.J., RUSSELL, R.M. 2002. Carotenoid bioavailability and bioconversion. Annual Review of Nutrition. 22: 483-504. 